JURNAL PANGAN DAN GIZI 9 (1): 16-26, April 2019

ISSN 2086-6429 (Online)

Tersedia online di http://jurnal.unimus.ac.id/index.php/JPDG

\title{
Efektivitas Sayur Bayam Terhadap Perubahan Kadar Hemoglobin Remaja Putri Di SMP 3 Kalasan, Sleman, Yogyakarta
}

\section{Effectiveness Of Spinach To Levels Of Hemoglobin Of Adolescent In Junior High School 3 Kalasan, Sleman, Yogyakarta}

\author{
Reza Iqbal Suhada ${ }^{1}$, Ayu Fitriani ${ }^{2}$, Fery Lusviana Widiany ${ }^{3}$ \\ ${ }^{1,2}$ Program Studi S1 Kesehatan Masyarakat Universitas Respati Yogyakarta \\ ${ }^{3}$ Program Studi S1 Ilmu Gizi Universitas Respati Yogyakarta \\ Korespondensi,email: rezasuhada4@gmail.com
}

\begin{abstract}
Anemia is one of the most common nutritional problems in the world, especially in developing countries. Consumption of vegetables and fruits at most of the provinces in Indonesisa showed a decrease, especially in DIY Province, One of causing the occurrence of nutritional problems is anemia. From preliminary study data obtained 20\% of female students In Junior High School 3 Kalasan had anemia. This research to know the effectiveness of giving spinach to change in levels of hemoglobin of female students In Junior High School 3 Kalasan. The type of research is quasi experiment with one group pre test post test design without control group. The sample of this research was female students. The sampling technique used simple random sampling as much as 35 students. The instrument used was Stick Hemoglobin Testing. Analysis of data used paired t-test. The result is there are differences of average hemoglobin level of respondents before treatment $(12,797 \mathrm{gr} / \mathrm{dl})$ and after treatment $(13,183 \mathrm{gr} / \mathrm{dl})$. And there is a significant differences of spinach to hemoglobin level of respondents ( $\rho$ value: 0,002). Spinach effectively affect to increase levels of hemoglobin of adolescent girls.
\end{abstract}

Keywords: Anemia, hemoglobin, adolescent, spinach.

\section{PENDAHULUAN}

Anemia adalah suatu kondisi kekurangan kadar hemoglobin $(\mathrm{Hb})$ dalam darah yang disebabkan oleh kurangnya asupan zat gizi yang diperlukan dalam proses pembentukan hemoglobin (Depkes,
2008). Anemia secara umum terjadi di seluruh dunia, terutama terjadi di negara berkembang. Di negara berkembang anemia yang terjadi pada wanita sebesar $45 \%$ sedangkan di negara maju sebesar $13 \%$. Anemia dapat diketahui dari rendahnya 
kadar hemoglobin dalam darah dari ambang batas yang disebabkan oleh rendahnya produksi sel darah merah (eritrosit), meningkatnya kerusakan eritrosit serta akibat kehilangan banyak darah saat menstruasi atau karena kecelakaan. Ada beberapa jenis anemia tapi yang paling sering terjadi yaitu anemia defisiensi besi (Fatmah, 2008).

Menurut data dari Riset Kesehatan Dasar, perilaku konsumsi sayur dan buah masyarakat Indonesia dari tahun 2007-2013 sebagian besar wilayah menunjukkan penurunan. Sedangkan di provinsi DIY, perilaku konsumsi sayur dan buah dari tahun 2007 86,0\% dan pada tahun 2013 menurun menjadi 84,0\% (Riskesdas, 2013).

Permasalahan gizi pada usia remaja merupakan kelanjutan dari permasalahan gizi pada usia anak salah satunya yaitu anemia defisiensi besi. Akibat dari kekurangan zat besi yaitu anemia dan keletihan. Pada usia remaja terutama remaja putri membutuhkan lebih banyak pengganti zat besi yang hilang akibat menstruasi. Anemia pada remaja putri merupakan suatu keadaan dimana kadar hemoglobin dalam darah kurang dari batas normal yaitu $\mathrm{Hb}$ normal menurut $W H O$ adalah $12 \mathrm{gr} / \mathrm{dl}$ (Arisman, 2010). Yang dimaksud remaja putri tersebut adalah masa transisi dari usia anak ke usia dewasa yang ditandai dengan adanya perubahan fisik dan mental. Perubahan fisik tersebut dapat ditandai dengan berfungsinya organ-organ reproduksi seperti terjadinya menstruasi (Depkes 2008). Pada seorang wanita masa remaja ditandai dengan mulainya menstruasi dan tumbuhnya buah dada. Sedangkan pada pria ditandai dengan perubahan suara, otot yang semakin membesar serta mimpi basah. Dengan berbagai keadaan tersebut remaja biasanya tidak mau dianggap sebagai anakanak lagi, tetapi jika dilihat dari berbagai kesiapannya mereka belum bisa dikatakan sebagai dewasa. Melihat hal tersebut 
sangatlah penting dalam memperhatikan proses perkembangan remaja secara fisik, emosional, maupun sosial. Ketiga hal tersebut tidak lepas dari pemenuhan nutrisi yang dibutuhkannya. Pemenuhan kebutuhan gizi saat usia remaja akan sangat mempengaruhi kondisi kesehatan dan kesejahteraanya di masa dewasa sampai lansia (Maryam,S. 2016).

Salah satu alternatif dalam memenuhi kebutuhan zat besi dapat dengan mengkonsumsi sayuran yang mengandung zat besi. Zat besi dapat ditemukan dalam sayur-sayuran, seperti bayam (Amaranthus $s p)$. Sayuran hijau seperti bayam merupakan sumber zat besi nonheme. Bayam yang dimasak mengandung zat besi sebanyak 8,3 $\mathrm{mg} / 100$ gram. Zat besi yang terdapat dalam bayam tersebut berguna untuk pembentukan hemoglobin dalam darah (Fatimah, S, 2009).

Bayam merupakan bahan makan sayuran yang paling tinggi mengandung zat besi yaitu 3,9 mg/100 gram dari pada bahan jenis sayuran yang lainnya, seperti sawi 2,9 mg, daun katuk 2,7 mg, kangkung 2,5 mg, daun singkong 2,0 mg (Marmi, 2016).

Tujuan dari penelitian ini adalah Untuk mengetahui efektivitas pemberian sayur bayam terhadap perubahan kadar hemoglobin remaja putri di SMP N 3 Kalasan, Sleman, Yogyakarta.

\section{METODE PENELITIAN}

Jenis penelitian ini merupakan penelitian kuantitatif dengan jenis studi eksperimen semu (quasi experiment studies) dengan desain penelitian pre and post test design without control group. Penelitian ini dilaksanakan pada bulan Juli 2017 s/d Agustus 2017 di SMP N 3 Kalasan Sleman Yogyakarta. Sampel dalam penelitian ini sebanyak 35 sampel dengan teknik simple random sampling.

Instrumen penelitian yang digunakan adalah Kuesioner digunakan untuk mengetahui karakteristik responden, keluhan yang dialami responden, dan hasil 
pemeriksaan kadar hemoglobin sebelum dan sesudah perlakuan. Stick Hemoglobin Testing untuk mengukur kadar hemoglobin responden. Lembar recall digunakan untuk mengetahui pola konsumsi responden selama penelitian berlangsung. Lembar observasi digunakan peneliti untuk mengetahui apakah selama penelitian responden menghabiskan sayur bayam atau tidak. Uji statistic yang digunakan adalah Paired t-Test.

\section{HASIL PENELITIAN}

\section{Tabel 1 Karakteristik Responden}

\begin{tabular}{lcc}
\hline Karakteristik & Jumlah (n) & Persen (\%) \\
\hline Umur (Tahun) & & \\
12 & 1 & 2.9 \\
13 & 16 & 45.7 \\
14 & 16 & 45.7 \\
15 & 2 & 5.7 \\
Pendidikan & & \\
Orang Tua & & \\
SD & 1 & 2.9 \\
SMP & 4 & 11.4 \\
SMA & 21 & 60.0 \\
S1 & 9 & 25.7 \\
Pekerjaan & & \\
Orang Tua & & \\
PNS & 3 & 8.6 \\
Pengacara & 1 & 2.9 \\
Wiraswasta & 9 & 25.7 \\
Karyawan & 12 & 34.3 \\
Swasta & 8 & 22.9 \\
Buruh & 2 & 5.7 \\
Pedagang & & \\
Status Anemia & & \\
Sebelum & & \\
\hline
\end{tabular}

\begin{tabular}{lcc}
\hline Perlakuan & & \\
Anemia & 6 & 17.1 \\
Tidak Anemia & 29 & 82.9 \\
Sesudah & & \\
Perlakuan & & \\
Anemia & 5 & 14.3 \\
Tidak Anemia & 30 & 85.7 \\
\hline Jumlah & 35 & 100.0 \\
\hline
\end{tabular}

Sumber: Data Primer, 2017

Pada tabel 1 menunjukkan bahwa dari 35 responden, frekuensi jumlah responden yang paling banyak berumur 13 tdan 14 tahun masing-masing berjumlah 16 $(45,7 \%)$. Frekuensi responden berdasarkan pendidikan orang tua responden paling banyak berpendidikan tamat SMA yaitu sebanyak $21(60,0 \%)$.

Distribusi frekuensi berdasarkan pekerjaan orang tua responden paling banyak bekerja sebagai karyawan swasta yaitu sejumlah 12 (34,3\%). Frekuensi responden berdasarkan status anemia, sebelum diberikan perlakuan responden dengan status anemia sebanyak $6(17,1 \%)$ responden dan sesudah diberikan perlakuan responden dengan status anemia sejumlah 5 $(14,3 \%)$ responden. 
Tabel 2 Hasil uji paired t-test

\begin{tabular}{llcccc}
\hline & & \multicolumn{2}{c}{ Paired Stats... } & $\begin{array}{c}\text { Sig (2- } \\
\text { tailed) }\end{array}$ \\
\hline & & Mean & N & $\begin{array}{c}\text { Std. } \\
\text { Deviation }\end{array}$ & \\
\hline Pair & $\begin{array}{l}\text { Hb } \\
\text { Pre }\end{array}$ & 12,797 & 35 & 0,8877 & \\
$\mathbf{1}$ & Hb \\
& Post & 13,183 & 35 & 1,0618 & 0,002 \\
\hline
\end{tabular}

Sumber: Data Primer, 2017

Berdasarkan tabel 2 dapat diketahui bahwa terdapat perbedaan rerata kadar hemoglobin responden sebelum perlakuan yaitu 12,797 gr/dl dan sesudah perlakuan yaitu 13,183 gr/dl. Dari hasil uji yang telah dilakukan, dapat diketahui nilai $\operatorname{sig}<\alpha$ atau $0,002<0,05$. Maka dapat disimpulkan menolak H0. Berarti ada perbedaan yang signifikan sebelum dan sesudah diberikan intervensi yaitu pemberian sayur bayam terhadap perubahan kadar hemoglobin responden.

\section{PEMBAHASAN}

\section{Umur}

Berdasarkan hasil analisis distribusi frekuensi responden didapatkan bahwa responden yang berumur 12 tahun berjumlah $1(2,9 \%)$ siswa, responden yang berumur 13 tahun berjumlah $16(45,7 \%)$ siswa, responden yang berumur 14 tahun berjumlah $16(45,7 \%)$ siswa, dan responden yang berumur 15 tahun berjumlah $2(5,7 \%)$ siswa. Dari hasil analisis tersebut dapat diketahui bahwa jumlah responden paling banyak dengan umur 13 dan 14 tahun yaitu berjumlah masing-masing 16 siswa dan jumlah responden yang paling sedikit umur 12 tahun yaitu berjumlah 1 siswa. Hasil penelitian ini sejalan dengan penelitian yang telah dilakukan oleh Pratiwi, E (2016) yang dalam hasil penelitiannya menyatakan bahwa responden yang memiliki pengetahuan baik $(51,2 \%)$ lebih banyak daripada responden yang memiliki pengetahuan kurang $(48,8 \%)$ (Pratiwi, E.,2016).

Dalam penelitian ini jumlah responden yang berumur 13 dan 14 tahun lebih banyak. Bahwa umur reponden tersebut dapat mempengaruhi tingkat pengetahuannya mengenai anemia. Hal 
tersebut dapat diketahui dari hasil pengukuran status anemia responden, bahwa responden yang tidak mengalami anemia jumlahnya lebih banyak dibandingkan dengan responden yang mengalami anemia.

\section{Pendidikan Orang Tua}

Berdasarkan hasil analisis distribusi frekuensi responden menurut pendidikan orang tua didapatkan bahwa tingkat pendidikan SD berjumlah $1(2,9 \%)$, tingkat pendidikan SMP berjumlah $4(11,4 \%)$, tingkat pendidikan SMA berjumlah 21 (60\%), dan tingkat pendidikan S1 berjumlah $9(25,7 \%)$. Dengan melihat hasil tersebut diketahui bahwa jumlah tingkat pendidikan orang tua responden paling banyak yaitu tingkat SMA dan yang paling sedikit yaitu tingkat SD. Hasil penelitian ini sejalan dengan penelitian yang telah dilakukan oleh Martini (2015) dengan hasil penelitian yang menyatakan bahwa pendidikan orang tua berhubungan dengan kejadian anemia di MAN 1 Metro. Karena tingkat pendidikan dapat mempengaruhi pengetahuan seseorang mengenai perilaku konsumsi makanan yang bergizi untuk anak. Sehingga semakin baik pendidikan orang tua maka semakin baik pula pola konsumsi makanan yang diberikan untuk anaknya (Martini, 2015).

Selain itu hasil penelitian ini juga sejalan dengan penelitian yang dilakukan oleh Gunatmaningsih, D., 2007) menyatakan bahwa ada hubungan yang signifikan antara tingkat pendapatan keluarga dengan kejadian anemia. Tingkat ekonomi keluarga merupakan faktor mendasar yang akan mempengaruhi segala aspek kehidupan dalam keluarga. Tingkat ekonomi terkait langsung dengan daya beli keluarga, baik daya beli terhadap makanan maupun daya beli terhadap pelayanan kesehatan yang lebih baik. Semakin tinggi pendapatan keluarga maka semakin mampu suatu keluarga untuk dapat membeli makanan yang bergizi untuk keluarga khususnya bagi anak. Sehingga gizi anak pun dapat 
tercukupi sesuai dengan kebutuhannya

(Gunatmaningsih, D., 2007).

\section{Pekerjaan Orang Tua}

Berdasarkan hasil analisis distribusi frekuensi responden menurut pekerjaan orang tua didapatkan bahwa orang tua responden yang bekerja sebagai PNS berjumlah $3(8,6 \%)$, orang tua responden yang bekerja sebagai Pengacara berjumlah 1 $(2,9 \%)$, orang tua responden yang bekerja sebagai Wiraswasta berjumlah $9(25,7 \%)$, orang tua responden yang bekerja sebagai Karyawan Swasta berjumlah 12 (34,3\%), orang tua responden yang bekerja sebagai Buruh berjumlah $8(22,9 \%)$, dan orang tua responden yang bekerja sebagai Pedagang berjumlah $2(5,7 \%)$. Dapat diketahui bahwa orang tua responden paling banyak bekerja sebagai Karyawan Swasta dan orang tua responden paling sedikit bekerja sebagai Pengacara. Hasil ini sejalan dengan penelitian yang telah dilakukan oleh Abdul Basith, dkk (2017) yang menyatakan bahwa terdapat hubungan antara tingkat pendapatan orang tua dengan kejadian anemia. Hasil penelitian menunjukkan bahwa orang tua responden lebih banyak yang sudah memiliki pekerjaan yang baik sehingga otomatis pendapatannya juga baik (Basith, A., Agustina, R., \& Diani, R, 2017).

Marmi (2016) menyebutkan bahwa salah satu faktor yang mempengaruhi status gizi remaja yaitu pendapatan keluarga. Pekerjaan orang tua secara langsung mempengaruhi pendapatan dari keluarga. Hal tersebut juga akan mempengaruhi pola perilaku konsumsi makanan keluarga tersebut. Sehingga semakin baik pekerjaan orang tua maka semakin baik pula pola konsumsi makanan keluarga (Marmi, 2016).

\section{Status Anemia}

Berdasarkan hasil analisis disribusi frekuensi responden menurut status anemia dapat diketahui bahwa sebelum diberikan perlakuan responden dengan status anemia sejumlah $6 \quad(17,1 \%)$ responden dan 
responden dengan status tidak anemia sejumlah $29(82,9 \%)$ responden. Sedangkan setelah diberikan perlakuan responden dengan status anemia sejumlah $5(14,3 \%)$ responden dan responden dengan status tidak anemia sejumlah $30(85,7 \%)$ responden.

Responden yang berstatus anemia sesudah diberikan perlakuan jumlahnya lebih sedikit dibandingkan dengan sebelum diberikan perlakuan. Artinya perlakuan yang diberikan kepada responden berupa sayur bayam dapat mempengaruhi status anemia responden menjadi lebih baik. Hasil penelitian tersebut sejalan dengan penelitian yang dilakukan oleh Rohmatika, D, dkk (2016) dalam penelitiannya menyatakan bahwa ada perbedaan rata-rata kadar hemoglobin darah responden sebelum dan sesudah diberikan ekstrak bayam hijau (Rohmatika, D., Supriyana., \& Ramlan, D., 2016).

Fatimah (2013) menyebutkan bahwa nilai cut of poin kategori anemia kelompok umur 12 hingga 13 tahun adalah 12,0 gr/dl. Seseorang yang kadar hemoglobinnya dibawah 12,0 gr/dl dinyatakan anemia dan dapat diketahui dari gejala-gejala yang dapat ditimbulkan seperti pucat, cepat pusing, nafsu makan berkurang, tidak ada tenaga, sesak napas (Maryam, S., 2016). Dari gejalagejala yang dapat ditimbulkan terhadap seseorang yang mengalami anemia maka seseorang tidak dapat dengan maksimal melakukan berbagai aktivitas belajar, bekerja dan kegiatan sehari-hari.

\section{Perubahan Kadar Hemoglobin}

Dari hasil analisis uji paired t-test didapatkan bahwa rerata kadar hemoglobin sebelum perlakuan pemberian sayur bayam yaitu 12,797 gr/dl sedangkan rerata kadar hemoglobin setelah perlakuan pemberian sayur bayam yaitu 13,183 gr/dl. Hasil penelitian ini sejalan dengan penelitian yang dilakukan oleh Rohmatika, dkk (2016) yang dalam hasil penelitiannya menyatakan bahwa ada perbedaan kadar hemoglobin 
darah sebelum dengan sesudah diberikan ekstrak bayam hijau. Kadar hemoglobin setelah perlakuan lebih besar dibandingkan dengan sebelum perlakuan (Rohmatika, D., Supriyana., \& Ramlan, D., 2016).

Bayam memiliki kandungan zat besi yang tinggi untuk mencegah terjadinya anemia. Kandungan zat besi dalam bayam berguna untuk proses pembentukan kadar hemoglobin dalam darah. Sehingga dengan mengkonsumsi bayam seseorang akan memiliki kadar hemoglobin dalam batas normal dan dapat mencegah terjadinya anemia (Adriani, M., \& Wijatmadi, B., 2014).

Efektivitas Pemberian Sayur Bayam Terhadap Perubahan Kadar Hemoglobin

Berdasarkan hasil analisis uji rerata kadar hemoglobin sebelum dan sesudah perlakuan menggunakan uji paired sample ttest didapatkan hasil yaitu $\operatorname{sig}<\alpha$ atau 0,002 $<0,05$, maka menolak H0. Sehingga dapat diketahui bahwa ada perbedaan yang signifikan sebelum dan sesudah diberikan perlakuan. Maka dapat disimpulkan bahwa sayur bayam efektif berpengaruh terhadap perubahan kadar hemoglobin. Hasil penelitian ini sejalan dengan penelitian yang dilakukan oleh Rohmatika, dkk (2016) yang dalam hasil penelitiannya menyatakan bahwa ada perbedaan pengaruh pemberian ekstrak bayam hijau dan pemberian tablet $\mathrm{Fe}$ dalam perubahan kadar hemoglobin ibu hamil (Rohmatika, D., Supriyana., \& Ramlan, D., 2016).

Sayur bayam mengandung zat besi yang diperlukan oleh tubuh untuk proses pembentukan hemoglobin (Adriani, M., \& Wijatmadi, B, 2014). Pada bagian dalam hemoglobin bersifat seperti lilin (waxy) dan bagian luar seperti sabun (soapy) yang mengakibatkan larut dalam air tetapi tidak dapat ditembus oleh air (impermeabel) (Saryono, 2009). Sehingga zat besi yang masuk ke dalam tubuh akan mudah diserap 
dan dapat membantu dalam proses meningkatkan kadar hemoglobin seseorang.

\section{KESIMPULAN}

1. Dalam penelitian ini sebagian besar responden dengan umur 13 dan 14 tahun, orang tua responden berpendidikan SMA berjumlah $21(60 \%)$, dengan pekerjaan orang tua responden sebagai Karyawan Swasta berjumlah $12 \quad(34,3 \%)$ serta jumlah responden yang berstatus anemia sebelum perlakuan sebanyak $6(17,1 \%)$ responden dan sesudah perlakuan sebanyak $5(14,3 \%)$ responden.

2. Rata-rata kadar hemoglobin sebelum perlakuan yaitu 12,797 gr/dl dengan standard deviasi 0,8877. Serta kadar hemoglobin maksimum 14,6 gr/dl dan kadar hemoglobin minimum 11 gr/dl.

3. Rata-rata kadar hemoglobin sesudah perlakuan yaitu 13,183 gr/dl dengan standard deviasi 1,0618. Serta kadar hemoglobin maksimum 15,9 gr/dl dan kadar hemoglobin minimum 10,8 gr/dl.

4. Pemberian sayur bayam efektif berpengaruh terhadap perubahan kadar hemoglobin remaja putri di SMP N 3 Kalasan dengan p-value 0,002.

\section{DAFTAR PUSTAKA}

Adriani, M., dan Wijatmadi, B. (2014). Pengantar Gizi Masyarakat. Jakarta: Kencana Prenada Media Group. Hlm 48-52.

Arisman, (2010), dalam Mariana, W., \& Khafidoh, N. (2013). Hubungan Status Gizi Dengan Kejadian Anemia Pada Remaja Putri Di Smk Swadaya Wilayah Kerja Puskesmas Karangdoro Kota Semarang Tahun 2013. Jurnal Kebidanan, 36. Hlm 36

Basith, A., Agustina, R., \& Diani, R. (2017). Internet. Faktor-Faktor Yang Berhubungan Dengan Kejadian Anemia Pada Remaja Putri. Jurnal Universitas Lambung Mangkurat, volume 5, no 1. http://3634-7264-1SM.pdf. Diakses pada 12 Oktober 2017.

Depkes RI. (2008). Internet. Pedoman Penanggulangan Anemia Gizi Untuk Remaja Putri dan Wanita Usia Subur (WUS). www.perpustakaan.depkes.go.id, diakses tanggal 18 Maret 2017. Hlm 1.

Fatmah, 2008, dalam Kristianti, S. (2014). Hubungan Anemia Dengan Siklus Menstruasi Pada Remaja Putri di SMA Negeri 1 Imogiri, Bantul, Yogyakarta, Tahun 2013. Jurnal Studi Pemuda , 34. Hlm 34.

Fatimah, S, 2009 dalam Rohmatika, D., Supriyana., \& Ramlan, D. (2016). Perbandingan Pengaruh Pemberian Ekstrak Bayam Hijau Dengan Preparat $\mathrm{Fe}$ Terhadap Perubahan Kadar Hemoglobin Ibu Hamil Pasien Puskesmas. Jurnal KesMaDaSka , 62. Hlm 62. 
Gunatmaningsih, D. (2007). Faktor-Faktor Yang Berhubungan Dengan Kejadian Anemia Pada Remaja Putri Di SMA $N \quad 1$ Brebes. Skripsi. Universitas Semarang.

lib.unnes.ac.id/1102/1/2676.pdf.

Diakses pada tanggal 22 November 2017.

Marmi. (2016). Gizi Dalam Kesehatan Reproduksi. Yogyakarta: Pustaka Pelajar. Hlm 166-351.

Martini. (2015). Internet. Faktor-Faktor Yang Berhubungan Dengan Kejadian Anemia Pada Remaja Putri Di MAN 1 Metro. Jurnal Kesehatan Metro Sai Wawai, volume VIII, no 1. http://ejurnal.poltekkes-

tjk.ac.id/index.php/JKM/article/view/ 162. Diakses pada 11 Oktober 2017.

Maryam, S. (2016). Gizi Dalam Kesehatan Reproduksi. Jakarta: Salemba Medika. hlm 204-219.

Pratiwi, E. (2016). Faktor-Faktor Yang Mempengaruhi Anemia Pada Siswi MTS Ciwandan. Skripsi. UIN Syarif Hidayatullah. uinjkt.ac.id/EKAPRATIWI-

FKIK.pdf. Diakses pada tanggal 22 November 2017.

Riskesdas. (2013). Riset Kesehatan Dasar. Jakarta: Kemenkes RI. Hlm 142-143.

Rohmatika, D., Supriyana., \& Ramlan, D. (2016). Perbandingan Pengaruh Pemberian Ekstrak Bayam Hijau Dengan Preparat Fe Terhadap Perubahan Kadar Hemoglobin Ibu Hamil Pasien Puskesmas. Jurnal KesMaDaSka, 66-67.

Saryono. (2009). Biokimia Respirasi. Yogyakarta: Nuha Medika. Hlm 6570. 